\title{
Inhibitory effects of Launaea taraxacifolia and \\ Strychnos spinosa leaves extract on an isolated digestive enzyme linked to type -2 -diabetes mellitus
}

\author{
Adinortey, M.B. (Corresponding Author)
}

Department of Biochemistry, School of Biological Sciences, College of Agriculture and Natural Sciences, University of Cape Coast, Cape Coast, Ghana. Email:

madinortey@ucc.edu.gh

Sarfo, J. K.

Department of Biochemistry, School of Biological Sciences, College of Agriculture and Natural Sciences, University of Cape Coast, Cape Coast, Ghana.

Adinortey, C. A.

Department of Molecular Biology and Biotechnology, School of Biological Sciences, College of Agriculture and Natural Sciences, University of Cape Coast, Cape Coast, Ghana.

Ofori, E. G.

Department of Biochemistry, School of Biological Sciences, College of Agriculture and Natural Sciences, University of Cape Coast, Cape Coast, Ghana.

Kwarteng J.

Department of Biochemistry, School of Biological Sciences, College of Agriculture and Natural Sciences, University of Cape Coast, Cape Coast, Ghana.

Afrifa, J.

Department of Medical Laboratory Science, School of Allied Sciences, University of Cape Coast, Cape Coast, Ghana 
Adjei-Owusu, J. F.

Department of Biochemistry, School of Biological Sciences, College of Agriculture and Natural Sciences, University of Cape Coast, Cape Coast, Ghana.

Received: February 12, 2018

Accepted: March 1, 2018

doi:10.5296/jbls.v9i2.12649

URL: https://doi.org/10.5296/jbls.v9i2.12649

\begin{abstract}
Background: The most prevalent type of diabetes mellitus (Type-2), is managed using many approaches, including the lowering of postprandial hyperglycaemia. Inhibition of key enzymes involved in carbohydrate breakdown such as $\alpha$-glucosidase and $\alpha$-amylase has been reported as a novel strategy to delay the absorption of glucose after meals. This study sought to determine the in vitro inhibitory potential of Launaea taraxacifolia and Strychnos spinosa leaf extracts on $\alpha$-glucosidase enzyme and also determine their modes of inhibiting the enzyme.
\end{abstract}

Materials and Methods: Plant extracts were prepared using soxhlet apparatus. Inhibitory effect of extracts at different concentrations and mode of inhibition were carried out using $\alpha$-glucosidase enzyme isolated from the small intestine of a guinea pig. Results: Extracts of Launaea taraxacifolia (LTE) and Strychnos spinosa (SSE) leaves showed $\alpha$-glucosidase inhibitory potential of approximately $69 \%$ and $79 \%$ respectively as compared to $73 \%$ for standard drug-acarbose at a maximum concentration of $1000 \mu \mathrm{g} / \mathrm{mL}$. The $\mathrm{IC}_{50}$ values recorded were $205.2 \pm 0.044 \mu \mathrm{g} / \mathrm{mL}, 129.4 \pm 0.094 \mu \mathrm{g} / \mathrm{mL}$ and $196.9 \pm 0.036 \mu \mathrm{g} / \mathrm{mL}$ for LTE, SSE and acarbose respectively. The Lineweaver Burk plot showed an uncompetitive mode of inhibition for both LTE and SSE as depicted by the lower $\mathrm{K}_{\mathrm{m}}$ and $\mathrm{V}_{\max }$ of enzyme inhibited by extracts compared to control. Conclusion: Extracts of Launaea taraxacifolia and Strychnos spinosa leaves showed significant inhibitory effect on an isolated intestinal $\alpha$-glucosidase enzyme in an uncompetitive mode

Keywords: Launaea taraxacifolia, Strychnos spinosa, $\alpha$-glucosidase, diabetes mellitus

\title{
1. Introduction
}

One of the leading metabolic and endocrine disorders affecting a substantial number of the world's population is diabetes mellitus (Ley et al., 2014). According to Wild et al. about 180 million people globally have the disorder and it's likely to increase twofold by the year 2030 . (Wild et al., 2004). Among the types of diabetes mellitus reported, type 2-diabetes mellitus, is most common ( $\mathrm{Li}$ et al., 2004). Type-2-diabetes mellitus is managed using many pharmacotherapeutic strategies, but one that is recommended by the Third Asia-Pacific Region Diabetes Treatment Guidelines as the first-line of treatment for lowering postprandial hyperglycaemia, is the use of $\alpha$-glucosidase inhibitors (AGIs) (Yin et al., 2014). Inhibition of enzymes like $\alpha$-glucosidase that digest carbohydrate is a beneficial strategy to impede the 
rapid absorption of glucose after meals (Bösenberg and van Zyl, 2008).

Reports indicate that there are several inimical consequences like flatulence, diarrhoea, abdominal pain and bloating associated with the use of synthetic AGIs such as Acarbose (Glucobay®), miglitol (Glyset®) and voglibose (Volix®, Basen ${ }^{\circledR}$ ) (Alikunhi, et al 2012; van de Laar, 2008; Campbell et al., 1996). Implicitly it is clear that management of DM with synthetic drugs that do not pose any adverse effects is still a challenge. This has led to research attention being given to natural products with enzyme inhibitory effects. Ghana is endowed with biodiversity, especially plants and no extensive effort has been made to assess the bioactivity of these plants that are used by Traditional Medicine Practitioners (TMP) in managing diabetes mellitus. Thus more research is needed in the drug discovery process, and as such necessitated this study on Launaea taraxacifolia, and Strychnos spinosa leaves, currently used by rural folks in Ghana for managing water retention disorders, conjunctivitis, proper bone fixation in infants dyslipidaemia, hypertension and diabetes mellitus (Adebisi, 2004).

Launaea taraxacifolia is a tropical plant, which is part of the Asteraceae family and is commonly known as African Lettuce. Its leaves are used traditionally for preparing meals and also as medicine in Ghana (Adinortey et al., 2012; Dickson et al., 2012). Evidence-based reports indicate that $L$. taraxacifolia leaves possess DNA protective effect and antioxidant activity (Adinortey et al., 2018), protective effects against cisplatin and gentamicin induced kidney damage (Kuatsienu et al., 2017; Adejuwon et al., 2014) antimicrobial and antiarthritic effects (Ololade et al., 2017) and hypolipidaemic properties (Koukoui et al., 2015).

Strychnos spinosa Lam. is a member of the family Loganiaceae and is commonly known as spiny monkey orange or green monkey orange tree. Though the ripe fruit is generally edible, some consider the unripe poisonous. The plant is found throughout Africa, Madagascar, India, Sri Lanka, Southeast Asia and the northern tropical part of Australia. Different parts of the plant are used traditionally for managing several disorders including diabetes mellitus, snakebite, peptic ulcer, wounds, breast milk stimulation, venereal diseases, leprosy, diarrhoea, and malaria fever (Kabine et al., 2015; Isa et al., 2014; Asase et al., 2005; Neuwinger, 1996).

Though these plants are used in the management of diabetes mellitus, there is sparse report of their effect on enzymes that digest carbohydrate, such as $\alpha$-glucosidase and $\alpha$-amylase that are known to play central role in increasing postprandial hyperglycaemia. The study thus aimed at evaluating the effect of extracts of Launaea taraxacifolia and Strychnos spinosa leaves on the activity of $\alpha$-glucosidase as well as determine their mode of inhibition.

\section{Materials and Methods}

\subsection{Chemicals and Equipment}

Para-nitrophenyl- $\alpha$-D-glucopyranoside ( $P$ NPG) (Sigma Aldrich, Germany), para-nitrophenol $(P N P)$ (Sigma Aldrich; Germany), Sodium dihydrogen Phosphate, Disodium Hydrogen Phosphate and Sodium carbonate were from Merck Chemical Supplies (Darmstadt, Germany). Equipment include Labomed UVD-3200 spectrophotometer, pH meter model NOV-210 (Nova Scientific Ltd., Korea), and Sartorius analytical balance. All other chemicals 
used, including solvents, were of analytical grade.

\subsection{Plant Material}

Plant material used were leaves of Launaea taraxacifolia and Strychnos spinosa. These plants were collected from around the environs of the University in February 2017. A curator at Herbarium section of University authenticated them.

\subsection{Preparation of plant extract}

Freshly harvested leaves of Launaea taraxacifolia and Strychnos spinosa were washed, cut into pieces, air dried for three weeks and subsequently put in an oven for 6 hours at $30{ }^{\circ} \mathrm{C}$. The dried crispy leaves were then ground to fine powder and stored at $4{ }^{\mathrm{O}} \mathrm{C}$. The extraction procedure was carried out using the Soxhlet apparatus. About $100 \mathrm{~g}$ of powdered sample of Launaea taraxacifolia was weighed and put in 1L of $70 \%$ aqueous methanol whereas Strychnos spinosa powder was put in $1 \mathrm{~L}$ of $70 \%$ aqueous ethanol. The extraction was carried out for 12 hours after which suction filtration was used to obtain a filtrate of the crude extract. The filtrate was concentrated with a rotary evaporator and dried in a desiccator for 2 weeks. The percentage yield of the extract was calculated.

\subsection{Methods for qualitative analysis of phytoconstituents}

Phytochemical composition of Launaea taraxacifolia and Strychnos spinosa leaves extract was analysed using the method described by Trease and Evans, 2002.

\subsection{Experimental animals and maintenance}

All experimental protocols were carried out with reference to the guidelines on care of experimental animals as provided by the Organization for Economic Cooperation and Development (OECD). Guinea pigs were fed on feed supplied by Ghana Agro Food Company Tema, Ghana and water ad libitum. They were subjected to a $12 \mathrm{~h}$ light and dark cycle at $(25 \pm 2){ }^{\mathrm{O}} \mathrm{C}$. All guinea pigs were allowed to acclimatize to their new environment for at least 14 days with adequate water and food before the start of the experiment.

\subsection{Isolation of $\alpha$-glucosidase enzyme from guinea pig intestine}

The procedure reported by Thilagam et al. 2013 was employed. Guinea pigs were fasted for about 20 hours, sacrificed by anaesthesia and part of the small intestines immediately below the duodenum and immediately above the cecum was cut and thoroughly rinsed in ice-cold saline. The intestine was homogenized in cold solution of $0.02 \mathrm{M}$ sodium phosphate ( $\mathrm{pH}$ 6.9) buffer. The ratio of small intestine (mass) to buffer volume used for homogenization was 1:2. The homogenate was then centrifuged at $12,000 \mathrm{~g}$ for 30 minutes at $-4{ }^{\mathrm{O}} \mathrm{C}$ and the supernatant was gently harvested and stored in polypropylene eppendorf tubes as enzyme source at $-20{ }^{\mathrm{O}} \mathrm{C}$.

\subsubsection{Confirmatory test for $\alpha$-glucosidase enzyme activity}

About $50 \mu \mathrm{L}$ of p-Nitrophenyl- $\alpha$-D-glucopyranoside ( $p \mathrm{NPG})$ solution $(3 \mathrm{mM})$, which is colourless was added to $50 \mu \mathrm{L}$ of enzyme source and incubated for 5 minutes at $25{ }^{\circ} \mathrm{C}$. About 
$2 \mathrm{~mL}$ of $0.1 \mathrm{M} \mathrm{Na}_{2} \mathrm{CO}_{3}$ solution was added after incubation. The reaction mixture was observed for the formation of a yellow-coloured paranitrophenol $(P N P)$ that gives an indication of the activity of $\alpha$-glucosidase enzyme (Dahlqvist, 1964).

\section{$2.7 \alpha$-glucosidase inhibition assay}

The inhibition potential of the plants leaf extracts on $\alpha$-glucosidase activity was investigated according to the procedure described by Pistia-Brueggeman and Hollingsworth, (2000) with slight modification, using $\alpha$-glucosidase obtained from guinea pig small intestine. About 50 $\mu \mathrm{L}$ of $\alpha$-glucosidase $(2.873 \mathrm{U} / \mathrm{mL})$ was preincubated with $50 \mu \mathrm{L}$ of different concentrations of (LTE / SSE): $200 \mu \mathrm{g} / \mathrm{mL}, 400 \mu \mathrm{g} / \mathrm{mL}, 600 \mu \mathrm{g} / \mathrm{mL}, 800 \mu \mathrm{g} / \mathrm{mL}, 1000 \mu \mathrm{g} / \mathrm{mL}$ ), for 10 minutes. Then $50 \mu \mathrm{L}$ of $0.3 \mathrm{mM}$ p-Nitrophenyl- $\alpha$-D-glucopyranoside ( $p$ NPG) was added as a substrate to initiate the reaction. The reaction mixture was incubated at room temperature for 20 minutes and stopped by adding $2 \mathrm{~mL}$ of $0.1 \mathrm{M} \mathrm{Na}_{2} \mathrm{CO}_{3}$. Acarbose was used as positive control and prepared in same concentrations as the extracts. It was incubated with the enzyme following the same procedure as described above. The $\alpha$-glucosidase activity was determined by measuring a yellow-coloured paranitrophenol product released from $p$ NPG at $405 \mathrm{~nm}$. A negative control was prepared using the same method replacing the extract with distilled water. Blanks were prepared for each concentration with the constituent but without enzyme. The inhibitory activity of extracts on $\alpha$-glucosidase was calculated as percentage inhibition.

$\%$ Inhibition $=\{[$ ABS Control-ABS extract $] /$ ABS Control $\}$ X 100

\section{8 a-glucosidase kinetics studies}

\subsubsection{Estimation of $\alpha-$ glucosidase activity}

The activity of the enzyme was determined by the procedure described by Dahlqvis, (1964) with minor modifications. A total of $50 \mu \mathrm{l}$ of varying concentrations $(1.27 \mathrm{mM}, 2.54 \mathrm{mM}$, $3.81 \mathrm{mM}, 5.08 \mathrm{mM}, 6.34 \mathrm{mM}$ ) of the substrate, p-Nitrophenyl- $\alpha$-D-glucopyranoside (PNPG) was incubated with $50 \mu \mathrm{l}$ of $\alpha$-glucosidase enzyme solution $(2.873 \mathrm{U} / \mathrm{mL})$ for 5 minutes at 25 ${ }^{\circ} \mathrm{C}$. The reactions were stopped with $2 \mathrm{ml}$ of $0.1 \mathrm{M} \mathrm{Na}_{2} \mathrm{CO}_{3}$ solutions. In order to determine $\alpha$-glucosidase enzyme activity, absorbance of yellow coloured p-nitrophenol $(P \mathrm{NP})$ released from $p$ NPG was measured at $405 \mathrm{~nm}$ using a spectrophotometer. Concentration of $P \mathrm{NP}$ product released per unit time was estimated using a $P$ NP standard curve and reaction rate or velocities were calculated by dividing extrapolated $P N P$ concentration by 5 minutes. A graph of 1/velocity was plotted against $1 /$ [substrate] to estimate the $K_{m}$ and $V_{\max }$ of the enzyme.

\subsubsection{Determination of mode of inhibition of extracts on $\alpha$-glucosidase enzyme}

The mode of inhibition of $\alpha$-glucosidase by plant extracts was determined using the method described by Kazeem et al (2013) with minor modification. Briefly, $50 \mu \mathrm{L}$ of the (1000 $\mu \mathrm{g} / \mathrm{mL}$ of LT and SSE), extracts were preincubated with $50 \mu \mathrm{L}$ of $\alpha$-glucosidase solution $(2.873 \mathrm{U} / \mathrm{mL})$ for 10 minutes at room temperature in two different set of tubes. In different tubes, $50 \mu \mathrm{L}$ of $\alpha$-glucosidase enzyme was preincubated with $50 \mu \mathrm{L}$ of sodium phosphate buffer (pH 6.9). About $50 \mu \mathrm{L}$ of $p$ NPG at increasing concentrations $(1.27 \mathrm{mM}, 2.54 \mathrm{mM}, 3.81$ $\mathrm{mM}, 5.08 \mathrm{mM}, 6.34 \mathrm{mM}$ ) was added to both sets of reaction mixtures to start the reaction. 


\section{Macrothink}

The mixtures were incubated for 5 minutes at room temperature, and $2 \mathrm{~mL}$ of $\mathrm{Na}_{2} \mathrm{CO}_{3}$ was added to stop the reaction.

Concentration of paranitrophenol $(P N P)$ released per minute was estimated by measuring absorbance of a coloured solution and extrapolating from a standard curve. The rate of reaction or reaction velocities $(\mathrm{mM} / \mathrm{min})$ were computed for by dividing each extrapolated concentration by 5 minutes. A Lineweaver-Burk graph was plotted and the kinetic parameters, $\mathrm{Km}$ and Vmax were estimated using the Michaelis-Menten equation.

\subsection{Data Analysis}

All results were presented as mean \pm SEM (standard error of mean) for triplicate measurements. The $\mathrm{IC}_{50}$ value of the test substance was determined through a nonlinear regression analysis of the dose response curve. Data were analyzed by one-way ANOVA followed by Bonferroni posthoc test using Graphpad Prism software US version 8 .

\section{Results}

Methanolic extract of Launaea taraxacifolia had a percentage yield of $14 \%$ whilst Strychnos spinosa recorded $26 \%$. The phytochemical screening of extracts from these plants indicated the presence of terpenoids, flavonoids, tannins, saponins, reducing sugars and alkaloids (Table 1).

Table 1. Qualitative screening of plant extracts

\begin{tabular}{|c|c|c|}
\hline Phytochemical & LTE & SSE \\
\hline Terpenoids & + & + \\
\hline Flavonoids & + & + \\
\hline Tannins & + & + \\
\hline Saponins & + & + \\
\hline Alkaloids & + & + \\
\hline Reducing sugars & + & + \\
\hline
\end{tabular}

+ : present- : absent, LTE: Launaea taraxacifolia extract. SSE: Strychnos spinosa extract

$\alpha$-glucosidase inhibitory potential of LTE and SSE were determined as presented in fig. 1 . Data analysis using ANOVA showed a significant difference $(\mathrm{P}<0.05)$ in percentage 


\section{Macrothink}

inhibitory activity amongst SSE, Acarbose and LTE in all concentrations tested. This observation was affirmed by a posthoc Bonferroni's multiple comparison test. At a maximum concentration of $1000 \mu \mathrm{g} / \mathrm{mL}$, SSE recorded a highest percentage inhibition of $78.97 \pm 0.335 \%$, followed by acarbose with a value of $73.30 \pm 0.34 \%$, whilst LTE showed the least percentage inhibition of $68.97 \pm 0.27 \%$. Investigation of potency of extracts at inhibiting $\alpha$-glucosidase enzyme using regression analysis showed $\mathrm{IC}_{50}$ values of $196.9 \pm 0.036 \mu \mathrm{g} / \mathrm{mL}, 205.2 \pm 0.044$ $\mu \mathrm{g} / \mathrm{mL}$ and $129.4 \pm 0.094 \mu \mathrm{g} / \mathrm{mL}$ respectively for acarbose, LTE and SSE. Results indicate that SSE appears to be the most potent glucosidase inhibitor $(\mathrm{p}<0.05)$, even better than a known standard drug-acarbose.

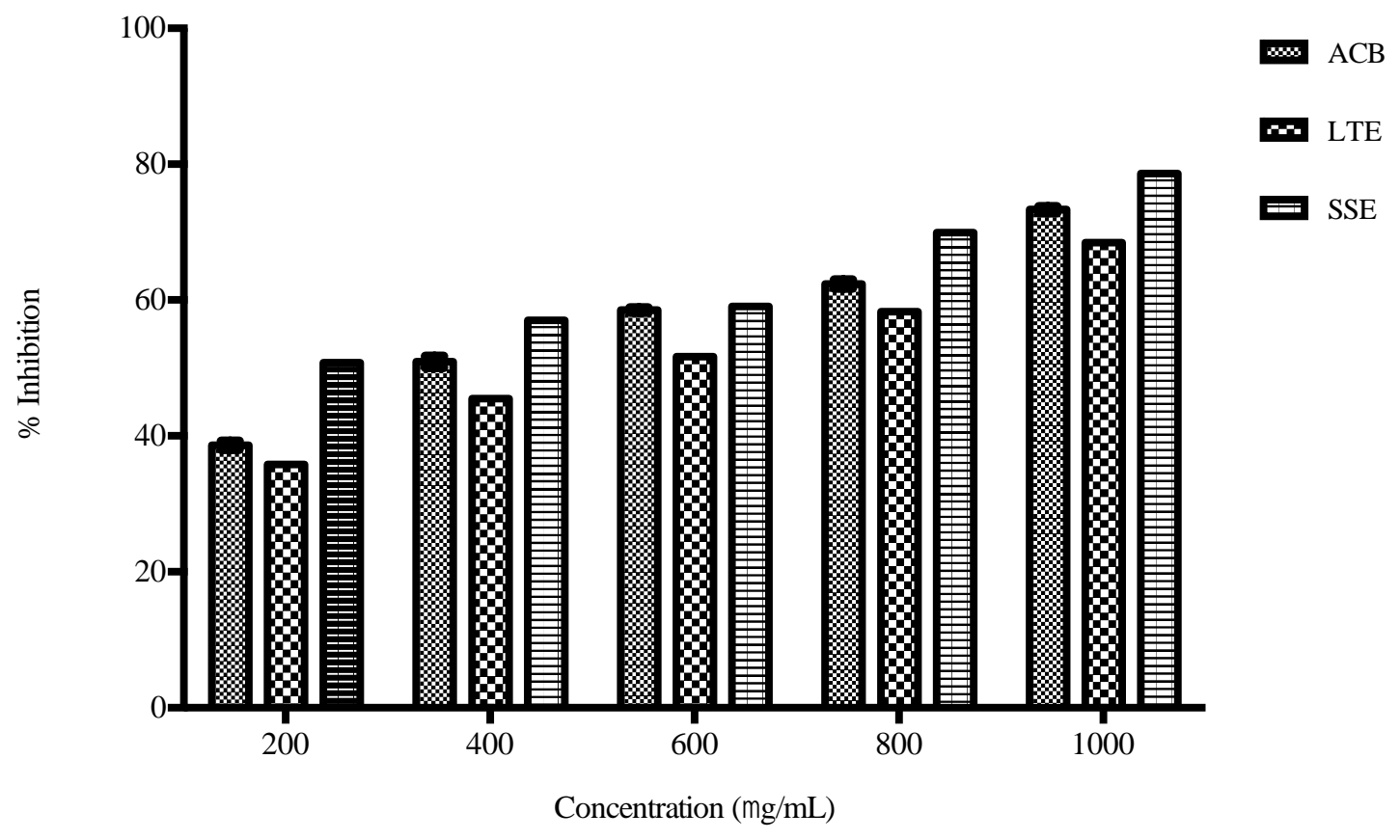

Fig. 1: Percentage inhibition of ACB, LTE and SSE on $\alpha$-glucosidase enzyme. 


\section{Macrothink}

The mode of inhibition of extracts on $\alpha$-glucosidase was ascertained from the Lineweaver-Burk plot that displayed an uncompetitive mode of inhibition of the enzyme (fig. 2). The use of Lineweaver-Burk plot allowed for estimation of kinetic parameters, $K_{m}$ (substrate concentration at half $\mathrm{V}_{\max }$ ) and $\mathrm{V}_{\max }$ (maximum reaction rate) in the presence of extract and absence (control). Estimated values for $\mathrm{K}_{\mathrm{m}}$ and $\mathrm{V}_{\max }$ for control that is enzyme without any inhibitor-extract was $9.194 \mathrm{mM}$ and $0.218 \mathrm{mM} / \mathrm{min}$ respectively. In the presence of $1000 \mu \mathrm{g} / \mathrm{mL}$ inhibitor, these kinetic parameters $-\mathrm{K}_{\mathrm{m}}$ and $\mathrm{V}_{\max }$ declined to $6.330 \mathrm{mM}$ and $0.152 \mathrm{mM} / \mathrm{min}$ respectively for LTE and $1.380 \mathrm{mM}$ and $0.031 \mathrm{mM} / \mathrm{min}$ respectively for SSE. The Michaelis-Menten plot in (fig. 3) indicates that, at increasing substrate ( $p$ NPG) concentrations, activity of $\alpha$-glucosidase increases in the absence of any extract but decreases steadily when LTE or SSE of $1000 \mu \mathrm{g} / \mathrm{mL}$ concentration was added. This was manifested explicitly at a substrate concentration of $4 \mathrm{mM}$ for both extracts (fig.3).

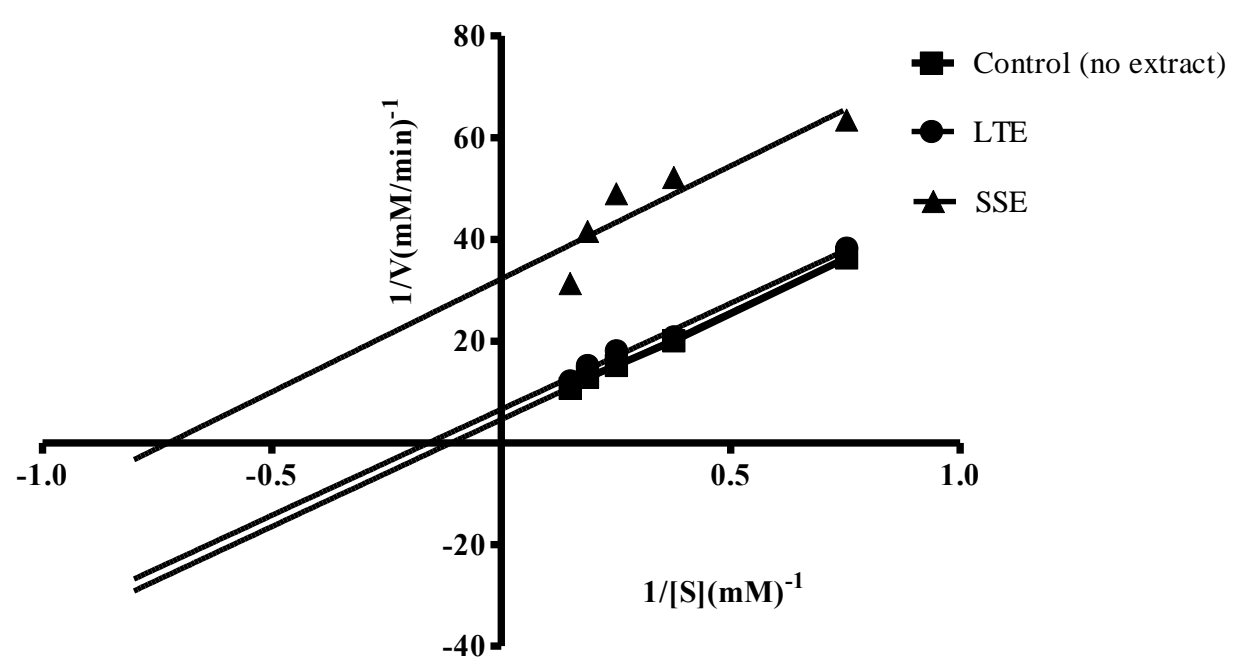

Fig 2: Lineweaver-Burk plot on the effect of LTE and SSE on $\alpha$-glucosidase 


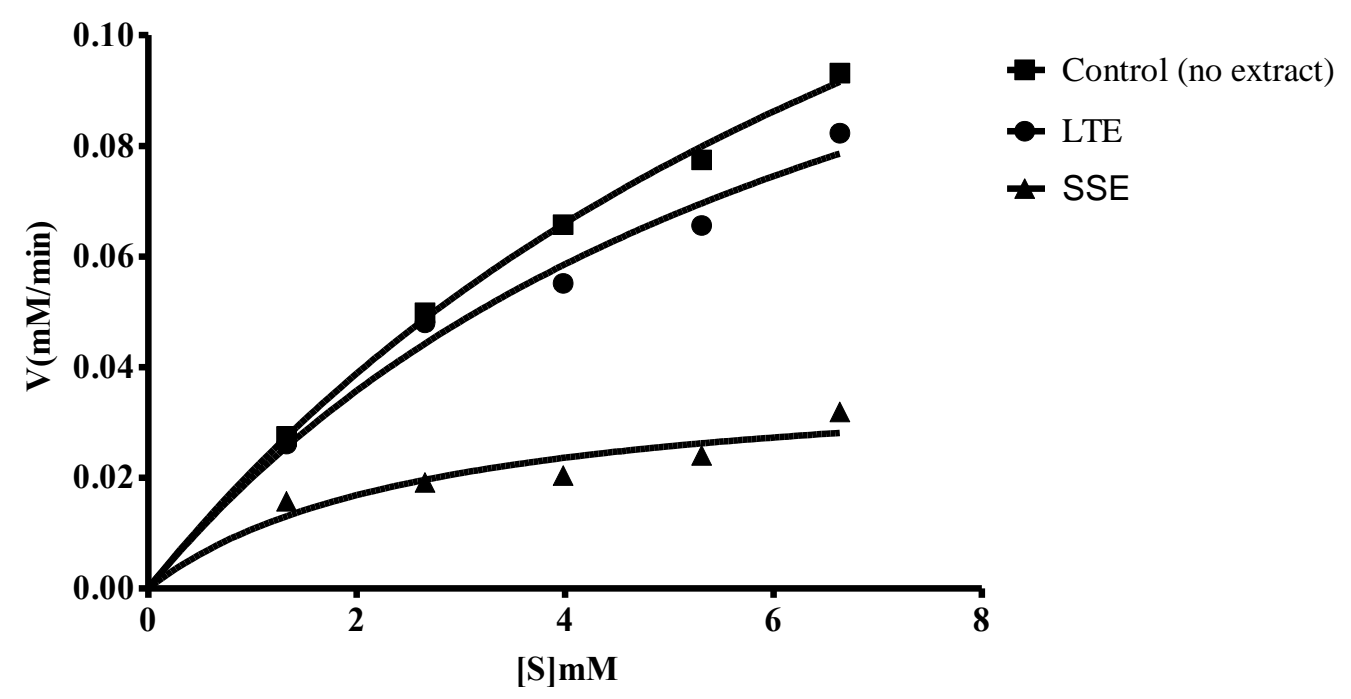

Fig 3. Michaelis-Menten curve on the effect of LTE and SSE on the activity of $\alpha$-glucosidase

\section{Discussion}

Glucosidase is an intestinal brush border enzyme, that catalyses the release of monosaccharaides and eventually its absorption in the small intestine (Van Beers et al 1995). Glucosidase is also considered a key enzyme in carbohydrate digestion. Synthetic glucosidase inhibitors are marketed as therapeutic drugs for Type-2- diabetes mellitus. Studies have however shown that, apart from these conventional treatment methods, natural remedies from medicinal plants are considered safe and effective alternatives in managing diabetes mellitus (Medagama et al., 2014). This research therefore sought to particularly assess the inhibitory property of two locally used plants; Launaea taraxacifolia and Strychnos spinosa used to manage persistent hyperglycaemia.

Extracts of Launaea taraxacifolia (LTE) and Strychnos spinosa (SSE) leaves demonstrated a marked $\alpha$-glucosidase inhibitory potential of approximately $69 \%$ and $79 \%$ respectively as compared to $73 \%$ for standard drug-acarbose at a maximum concentration of $1000 \mu \mathrm{g} / \mathrm{mL}$. Studies conducted elsewhere have reported that $\alpha$-glucosidase inhibitory activity of acarbose ranges from 55 to $82 \%$ (Mohamed et al., 2012; Perez-Gutierrez et al., 2012). The observation regarding acarbose percentage inhibition in this study is not contrary to what have been reported by Mohamed et al., (2012) and Perez-Gutierrez et al., (2012). SSE recorded the highest percentage inhibition at the maximum concentration used in this study. The $\mathrm{IC}_{50}$ value, which is the concentration of test substance at which $50 \%$ of enzyme activity is inhibited, was significantly different amongst the three different test substances. The significant difference in these values depicts the fact that SSE could be better than LTE and acarbose during pharmacotherapy. The $\mathrm{IC}_{50}$ values of launaea taraxacifolia and Strychnos spinosa leaves extract recorded in this study is lower than that of Cyperus esculentus (Sabiu et al., 2017), Adiantum caudatum and Celosis argentea (Telagari et al., 2015) but higher than what has been reported for Cissus cornifolia (Chipiti et al., 2017). 


\section{Macrothink}

The nature of Lineweaver-Burk plot is such that in an uncompetitive mode of inhibition, $\mathrm{K}_{\mathrm{m}}$ and $\mathrm{V}_{\max }$ are lowered or decreased in the presence of an inhibitor (Nelson, et al 2008). In this study, both extracts (LTE and SSE) demonstrated an uncompetitive inhibition on $\alpha$-glucosidase enzyme as confirmed by the kinetic parameters computed. The decline in $\mathrm{K}_{\mathrm{m}}$ and $v_{\max }$ values displayed by LTE and SSE could be due to the presence of some active ingredients that may be present in these plants extracts. Generally, an uncompetitive inhibitor binds at an allosteric site which is distinct from the enzyme's active site. Another characteristic feature of this type of inhibition is that, the inhibitor binds to only the enzyme-substrate (ES) complex. This allosteric interaction causes a conformational change in the globular structure of the enzyme thereby reducing the catalytic efficiency of the enzyme in converting substrate to product (Nelson et al., 2008). This implies that plant extracts investigated in this study possess active compounds capable of binding to allosteric sites on the ES ( $\alpha$-glucosidase- $p$ NPG) complex and cause a reduction in the catalytic efficiency of $\alpha$-glucosidase. This mechanism may have accounted for the decline in the enzyme's reaction velocity when inhibitors (LTE and SSE) were introduced.

Several important secondary metabolites are noted as contributing to therapeutic effectiveness in many plant natural products. Phytochemicals namely terpenoids, flavonoids, tannins, saponins and alkaloid have been reported to be present in methanolic extract of Launaea taraxacifolia leaves and also in ethanolic extract Strychnos spinosa leaves (Isa et al., 2014). This is not different from what has been observed in this study regarding these plants. There is evidence illustrating the inhibitory effects of phytochemicals such as flavonoids, on $\alpha$-glucosidase enzyme (Wei et al., 2015; Zhang et al., 2015; Dendup, et al., 2014). It is clear from this study, that extracts of Lauanea taraxacifola and Strychnos spinosa leaf displayed effective inhibition against $\alpha$-glucosidase enzyme and this may be associated with the synergistic effect of these phytochemical constituents present in the leaf extracts. The inhibitory property of Lauanea taraxacifola and Strychnos spinosa leaves extracts could be explored to control postprandial hyperglycaemia in type-2 diabetes mellitus individuals.

\section{Conclusion}

Extracts of Launaea taraxacifolia and Strychnos spinosa leaves displayed effective in vitro inhibition against isolated intestinal $\alpha$-glucosidase enzyme in an uncompetitive mode. The study also concludes that Launaea taraxacifolia and Strychnos spinosa contain bioactive compound that may be sources of lead compounds for $\alpha$-glucosidase inhibitors.

\section{References}

Adebisi, A. A. (2004). Launaea taraxacifolia (Willd.) Amin ex C. Jeffrey. PROTA, 2.

Adejuwon A, Femi-Akinlosotu O, Omirinde J, Owolabi O, Afodun A. Launaea taraxacifolia ameliorates cisplatin-induced hepato-renal injury. European Journal of Medicinal Plants 2014; 4: 528 .

Adinortey MB, Ansah C, Weremfo A, Adinortey CA, Adukpo GE, Ameyaw EO, et al. (2018). DNA damage protecting activity and antioxidant potential of Launaea taraxacifolia leaves extract. Journal of Natural Science, Biology and Medicine, 9, 6-13. 
Adinortey MB, Sarfo JK, Quayson ET, Weremfo A, Adinortey CA, Ekloh W, et al. (2012). Phytochemical screening, proximate and mineral composition of Launaea taraxacifolia leaves. Research Journal of Medicinal Plant, 6(2), 171-179.

Alikunhi, N. M., Kandasamy, K., Manoharan, C., \& Subramanian, M. (2012). Insulin-like antigen of mangrove leaves and its anti-diabetic activity in alloxan-induced diabetic rats. Natural Product Research, 26(12), 1161-1166.

Arawande, J. O., Amoo, I. A., \& Lajide, L. (2013). Chemical and phytochemical composition of wild lettuce Launaea taraxacifolia. Journal of Applied Phytotechnology in Environmental Sanitation, 2(1), 25-30.

Asase, A., Oteng-Yeboah, A. A., Odamtten, G. T., \& Simmonds, M. S. (2005). Ethnobotanical study of some Ghanaian anti-malarial plants. Journal of Ethnopharmacology, 99(2), 273-279.

Bösenberg, L. H., \& van Zyl, D. G. (2008). The mechanism of action of oral antidiabetic drugs: a review of recent literature. Journal of Endocrinology, Metabolism and Diabetes of South Africa, 13(3), 80-88.

Campbell, L. K., White, J. R., \& Campbell, R. K. (1996). Acarbose: its role in the treatment of diabetes mellitus. Annals of Pharmacotherapy, 30(11), 1255-1262.

Chipiti, T., Ibrahim, M. A., Singh, M., \& Islam, M. S. (2017). In vitro $\alpha$-amylase and $\alpha$-glucosidase Inhibitory and Cytotoxic Activities of Extracts from Cissus cornifolia Planch Parts. Pharmacognosy Magazine, 13(Suppl 2), S329.

Dahlqvist, A. (1964). Method for assay of intestinal disaccharidases. Analytical Biochemistry, $7,18,25$.

Dendup, T., Prachyawarakorn, V., Pansanit, A., Mahidol, C., Ruchirawat, S., \& Kittakoop, P. (2014). $\alpha$-Glucosidase inhibitory activities of isoflavanones, isoflavones, and pterocarpans from Mucuna pruriens. Planta Medica, 80(07), 604-608.

Dickson RA, Annan K, Fleischer TC, Amponsah IK, Nsiah K, Oteng JA (2012). Phytochemical investigations and nutritive potential of eight selected plants from Ghana. Journal of Pharmacy and Nutrition Sciences, 2(2):172-7.

Evans, W. C. (2002). Trease and Evans' Pharmacognosy $15^{\text {th }}$ edition Elsevier Health Sciences New York. Chapter 6 References, 21-24.

Isa, A. I., Awouafack, M. D., Dzoyem, J. P., Aliyu, M., Magaji, R. A., Ayo, J. O., \& Eloff, J. N. (2014). Some Strychnos spinosa (Loganiaceae) leaf extracts and fractions have good antimicrobial activities and low cytotoxicities. BMC complementary and alternative medicine, 14(1), 456.

Kabine, O., Mamadou, B. S., Fatoumata, B., Namagan, K., Luopou, H. N., \& Mamadou, B. A. (2015). Anti-oxidative activity of fruit extracts of some medicinal plants used against chronic diseases (diabetes, hypertension) in Kankan, Guinea. Journal of Plant Science, 3, 1-5.

Kazeem, M. I., Adamson, J. O., \& Ogunwande, I. A. (2013). Modes of inhibition of 
$\alpha$-amylase and $\alpha$-glucosidase by aqueous extract of Morinda lucida Benth leaf. BioMed Research International, 2013.

Koukoui O, Agbangnan P, Boucherie S, Yovo M, Nusse O, Combettes L, et al. Phytochemical study and evaluation of cytotoxicity, antioxidant and hypolipidaemic properties of Launaea taraxacifolia leaves extracts on cell lines HepG2 and PLB985. American Journal of Plant Sciences. 2015; 6:1768-1779.

Koukoui, O., Agbangnan, P., Boucherie, S., Yovo, M., Nusse, O., Combettes, L., \& Sohounhloué, D. (2015). Phytochemical study and evaluation of cytotoxicity, antioxidant and hypolipidemic properties of Launaea taraxacifolia leaves extracts on cell lines HepG2 and PLB985. American Journal of Plant Sciences, 6(11), 1768.

Koukoui, O., Senou, M., Agbangnan, P., Seton, S., Koumayo, F., Azonbakin, S., ... \& Sezan, A. (2017). Effective in vivo cholesterol and triglycerides lowering activities of hydroethanolic extract of Launaea taraxacifolia leaves. International Journal of Pharmaceutical Sciences and Research, 8(5), 2040.

Kuatsienu, L. E., Ansah, C., \& Adinortey, M. B. (2017). Toxicological evaluation and protective effect of ethanolic leaf extract of Launaea taraxacifolia on gentamicin induced rat kidney injury. Asian Pacific Journal of Tropical Biomedicine, 7(7), 640-646.

Ley, S. H., Hamdy, O., Mohan, V., \& Hu, F. B. (2014). Prevention and management of type 2 diabetes: dietary components and nutritional strategies. The Lancet, 383(9933), 1999-2007.

Li, W. L., Zheng, H. C., Bukuru, J., \& De Kimpe, N. (2004). Natural medicines used in the traditional Chinese medical system for therapy of diabetes mellitus. Journal of Ethnopharmacology, 92(1), 1-21.

Medagama, Arjuna B., and Ruwanthi Bandara. The use of Complementary and Alternative Medicines (CAMs) in the treatment of diabetes mellitus: is continued use safe and effective? Nutrition journal 13.1 (2014): 102.

Mohamed, E. A. H., Siddiqui, M. J. A., Ang, L. F., Sadikun, A., Chan, S. H., Tan, S. C., ... \& Yam, M. F. (2012). Potent $\alpha$-glucosidase and $\alpha$-amylase inhibitory activities of standardized $50 \%$ ethanolic extracts and sinensetin from Orthosiphon stamineus Benth as anti-diabetic mechanism. BMC complementary and alternative medicine, 12(1), 176.

Nelson, D. L., Lehninger, A. L., \& Cox, M. M. (2008). Lehninger principles of biochemistry. Macmillan.

Neuwinger, H. D. (1996). African ethnobotany: poisons and drugs: chemistry, pharmacology, toxicology. CRC Press.

Ololade ZS, Kuyooro SE, Ogunmola OO, Abiona OO. Phytochemical, antioxidant, anti-Arthritic, anti-inflammatory and bactericidal potentials of the leaf extract of Lactuca taraxacifolia. Global Journal of Medical Research 2017; 17 (2): 19-28

Perez-Gutierrez, R. M., \& Damian-Guzman, M. (2012). Meliacinolin: a potent $\alpha$-glucosidase 


\section{Macrothink}

Journal of Biology and Life Science

ISSN 2157-6076

2018, Vol. 9, No. 2

and $\alpha$-amylase inhibitor isolated from Azadirachta indica leaves and in vivo antidiabetic property in streptozotocin-nicotinamide-induced type 2 diabetes in mice. Biological and Pharmaceutical Bulletin, 35(9), 1516-1524.

Pistia-Brueggeman, G., \& Hollingsworth, R. I. (2001). A preparation and screening strategy for glycosidase inhibitors. Tetrahedron, 57(42), 8773-8778.

Sabiu, S., Ajani, E. O., Sunmonu, T. O., \& Ashafa, A. O. T. (2017). Kinetics of modulatory role of Cyperus esculentus L. on the specific activity of key carbohydrate metabolizing enzymes. African Journal of Traditional, Complementary, and Alternative Medicines, 14(4), 46.

Telagari, M., \& Hullatti, K. (2015). In-vitro $\alpha$-amylase and $\alpha$-glucosidase inhibitory activity of Adiantum caudatum Linn. and Celosia argentea Linn. extracts and fractions. Indian journal of pharmacology, 47(4), 425.

Thilagam, E., Parimaladevi, B., Kumarappan, C., \& Mandal, S. C. (2013). $\alpha$-Glucosidase and $\alpha$-amylase inhibitory activity of Senna surattensis. Journal of acupuncture and meridian studies, 6(1), 24-30.

Van Beers, E. H., Büller, H. A., Grand, R. J., Einerhand, A. W., \& Dekker, J. (1995). Intestinal brush border glycohydrolases: structure, function, and development. Critical reviews in biochemistry and molecular biology, 30(3), 197-262.

van de Laar, F. A. (2008). Alpha-glucosidase inhibitors in the early treatment of type 2 diabetes. Vascular health and risk management, 4(6), 1189.

Wei, Q., Ji, X. Y., Xu, F., Li, Q. R., \& Yin, H. (2015). Chemical constituents from leaves of Hibiscus syriacus and their $\alpha$-glucosidase inhibitory activities. Zhong yao cai= Zhongyaocai= Journal of Chinese medicinal materials, 38(5), 975-979.

Wild, S., Roglic, G., Green, A., Sicree, R., \& King, H. (2004). Global prevalence of diabetes: estimates for the year 2000 and projections for 2030. Diabetes care, 27(5), 1047-1053.

Yin, Z., Zhang, W., Feng, F., Zhang, Y., \& Kang, W. (2014). $\alpha$-Glucosidase inhibitors isolated from medicinal plants. Food Science and Human Wellness, 3(3-4), 136-174.

Zhang, Y. L., Luo, J. G., Wan, C. X., Zhou, Z. B., \& Kong, L. Y. (2015). Four New Flavonoids with $\alpha$-glucosidase inhibitory activities from Morus alba var. tatarica. Chemistry \& biodiversity, 12(11), 1768-1776. 


\section{Copyright Disclaimer}

Copyright for this article is retained by the author(s), with first publication rights granted to the journal.

This is an open-access article distributed under the terms and conditions of the Creative Commons Attribution license (http://creativecommons.org/licenses/by/3.0/). 